\title{
Model Flipped Classroom dan Discovery Learning terhadap Kemampuan Pemahaman Konsep dan Pemecahan Masalah Matematis
}

\author{
Lutfiatul Khofifah $^{1}$, Nanang Supriadi ${ }^{2}$, M. Syazali ${ }^{3}$ \\ ${ }^{1,2}$ Universitas Islam Negeri Raden Intan Lampung \\ ${ }^{3}$ Universitas Pertahanan \\ *lutfiatulkhofifah22@gmail.com
}

\begin{tabular}{|l|l|l|l|}
\hline Received : 04-11-2020 & Revised: 17-05-2021 & Accepted: 23-05-2021 & Published: 06-06-2021 \\
\hline
\end{tabular}

\begin{abstract}
ABSTRAK
Tujuan penelitian ini untuk mengetahui pengaruh model pembelajaran (flipped classroom dan discovery learning) terhadap kemampuan pemahaman konsep, pengaruh model pembelajaran (flipped classroom dan discovery learning) terhadap kemampuan pemecahan masalah matematis, dan pengaruh model pembelajaran (flipped classroom dan discovery learning) terhadap kemampuan pemahaman konsep dan pemecahan masalah matematis. Penelitian ini dilakukan di SMA Negeri 1 Sumber Jaya. Jenis eksperimen yang digunakan adalah Quasy Experimental Design, dengan desain Posttest Only Control Group Design. Populasinya adalah peserta didik kelas XI dan sampel penelitian adalah XI IPA 1 berjumlah 31 peserta didik sebagai kelas eksperimen 1 dengan penerapan model flipped classroom, XI IPA 2 berjumlah 31 peserta didik sebagai kelas eksperimen 2 dengan penerapan model discovery learning, dan XI IPA 3 berjumlah 31 peserta didik sebagai kelas kontrol dengan penerapan model direct instruction. Teknik pengumpulan data menggunakan observasi dan tes. Analisis data menggunakan uji Manova dan dilakukan uji lanjutan menggunakan uji Tukey. Penelitian ini menghasilkan adanya pengaruh model pembelajaran (flipped classroom dan discovery learning) terhadap kemampuan pemahaman konsep, adanya pengaruh model pembelajaran (flipped classroom dan discovery learning) terhadap kemampuan pemecahan masalah dan adanya pengaruh model pembelajaran (flipped classroom dan discovery learning) terhadap kemampuan pemahaman konsep dan pemecahan masalah matematis.
\end{abstract}

Kata Kunci : discovery learning, flipped classroom, pemahaman konsep, pemecahan masalah matematis

\begin{abstract}
The purpose of this study was to determine the effect of learning models (flipped classrooms and discovery learning) on the ability to understand concepts, the effect of learning models (flipped classrooms and discovery learning) on mathematical problem solving abilities, and the effect of learning models (flipped classrooms and discovery learning) on comprehension abilities. concepts and mathematical problem solving. This research was conducted at SMA Negeri 1 Sumber Jaya. The type of experiment used is Quasy Experimental Design, with a Posttest Only Control Group Design design. The population was students of class XI and the research sample was XI IPA 1 totaling 31 students as experimental class 1 with the application of the model flipped classroom, XI IPA 2 totaling 31 students as experimental class 2 with the application of models discovery learning, and XI IPA 3 totaling 31 students as a control class with the application of the direct instruction model. Data collection techniques using observation and tests. Data analysis used the Manova test and further tests were carried out using the Tukey test. This study resulted in the influence of the learning model (flipped classroom and discovery learning) on the ability to understand concepts, the influence of the learning model (flipped classroom and discovery learning) on problem solving abilities and the influence of the learning model (flipped classroom and discovery learning) on the ability to understand concepts. and mathematical problem solving.
\end{abstract}

Keywords : concept understanding, discovery learning, flipped classroom, mathematical problem solving 


\section{PENDAHULUAN}

Berdasarkan proses pengamatan yang di lakukan di Indonesia, peserta didik masih cenderung pasif dikarenakan beberapa dari guru matematika masih terbiasa menggunakan metode ceramah yang penyampainnya masih cenderung monoton dalam proses mengajar (Septian \& Ramadhanty, 2020). Indonesia masih perlu penanganan yang serius, bukan hanya dalam pembangunan sarana dan prasarana saja dalam hal pendidikan namun usaha untuk meningkatkan daya serap dan pemahaman peserta didik dalam proses pembelajaran (Hikmawati, Nurcahyono, \& Balkist, 2019; Khoirotunnisa, 2017; Monariska, 2017).

Banyak cara yang dapat dilakukan untuk untuk meningkatkan daya serap dan pemahaman peserta didik salah satunya mengembangkan kemampuan matematis peserta didik (Jusniani, 2018; Widiyawati, Septian, \& Inayah, 2020). Kemampuan matematis yang harus dikuasai peserta didik diantaranya kemampuan pemahaman konsep dan pemecahan masalah matematis. Bloom (Hadi, 2003) berpendapat bahwa pemahaman merupakan kemampuan menangkap pemahaman materi yang disuguhkan dalam bentuk yang bisa dimengerti, mampu memberi interpretasi dan dapat mengklasifikasikannya (Kusmawati and Ginanjar S, 2016). Kemampuan peserta didik dalam menyerap dan memahami ide-ide matematika disebut pemahaman kemampuan konsep matematis. Sedangkan kemampuan pemecahan masalah adalah kemampuan menggunakan pengetahuan atau konsep yang sudah ada untuk menjawab persoalan yang sulit dipecahkan atau yang belum terjawab (Septian, Darhim, \& Prabawanto, 2020). Peserta didik diberi kesempatan untuk mengembangkan ide matematika dan pemahaman konseptual (Widyastuti, 2015).

Fakta di lapangan menunjukan bahwa kemampuan pemahaman konsep dan pemecahan masalah matematis peserta didik kelas XI SMA Negeri 1 Sumber Jaya masih tergolong rendah dengan KKM yaitu 72. Hasil tes kemampuan pemahaman konsep menunjukan bahwa 94,62\% peserta didik belum mencapai Kriteria Ketuntasan Minimum dan pada tes kemampuan pemecahan masalah 93,54\% peserta didik belum mencapai Kriteria Ketuntasan Minimum. Hal ini disebabkan oleh peserta didik yang mengalami kesulitan dalam menerapkan konsep untuk menyelesaikan masalah yang terdapat dalam soal, dalam proses pembelajaran peserta didik masih mengandalkan guru sebagai penyampai materi, dan peserta didik belum mampu belajar mandiri untuk mendapatkan materi pembelajaran.

Rendahnya kemampuan pemahaman konsep dan kemampuan pemecahan masalah matematis peserta didik dan pentingnya kemampuan pemahaman konsep dan kemampuan 
pemecahan masalah matematis bagi peserta didik maka diperlukan adanya model pembelajaran yang sesuai dalam upaya meningkatkan kemampuan pemahaman konsep dan kemampuan pemecahan masalah matematis. Diperlukan model pembelajaran yang dapat melatih kemandirian peserta didik serta model pembelajaran yang didukung dengan kemajuan teknologi dan disesuaikan dengan perkembangan zaman sehingga peserta didik mampu menemukan secara konsep-konsep baru yang dapat diterapkan dalam pemecahan masalah. Penerapan model pembelajaran yang tepat, akan mampu memengaruhi keberhasilan peserta didik dalam proses pembelajaran.

Sebagai alternatif, model pembelajaran yang diterapkan yaitu model pembelajaran flipped classroom dan discovery learning. Konsep inti dari model pembelajaran flipped classroom adalah membalik atau mengubah kegiatan pembelajaran peserta didik dimana tugas yang biasa dikerjakan di rumah, peserta didik melakukannya di sekolah dan proses pembelajaran yang biasanya dilakukan di sekolah peserta didik melaksanakannya di rumah (Hayati, 2018). Discovery learning berusaha agar peserta didik belajar untuk merumuskan masalah, menguji hipotesis, menarik kesimpulan dan menyajikannya (Jarwan, 2018). Kedua model tersebut dapat membatu peserta didik untuk belajar lebih mandiri dalam memahami dan mendalami konsep untuk menyelesaikan suatu permasalahan matematika.

Hasil dari penelitian menyebutkan bahwa dengan diterapkannya model pembelajaran flipped classroom pemahaman konsep peserta didik lebih baik dibandingkan dengan metode ceramah (Saputra dan Mujib, 2018). Penelitian lain di SMP N 2 Karanganyar menunjukan dengan penerapan model flipped classroom kemampuan pemecahan masalah dapat mencapai KKM, dan kemampuan pemecahan masalah dengan model flipped classroom lebih baik dibandingkan dengan model PBL (Karimah, 2018).

Selain flipped classroom, discovery learning juga dijadikan sebagai model untuk meningkatan kemampuan pemahaman konsep dan pemecahan masalah. Hasil penelitian pada peserta didik kelas XI IPA SMA N 5 Singkawang menunjukan bahwa terdapat perbedaan kemampuan pemahaman konsep sebelum dan sesudah diterapkan model discovery learning, peserta didik menjadi lebih aktif sehingga aktivitas peserta didik mengalami peningkatan (Trianingsih, dkk., 2019). Penelitian lain menujukan kemampuan pemecahan masalah matematis peserta didik kelas VIII di SMP Islam Abata Malausma dengan diterapkannya model discovery learning meningkat dengan sangat baik dan aktivitas peserta didik sebesar $80 \%$ dalam kategori baik menggunakan model discovery learning (Nurhasanah, dkk., 2018). 
Berdasarkan permasalahan kondisi peserta didik di SMA Negeri 1 Sumber Jaya dan melihat dari penelitian-penelitian sebelumnya yang sudah diuraikan di atas tujuan penelitian ini adalah untuk mengetahui pengaruh dari dua model sekaligus (flipped classroom dan discovery learning) terhadap kemampuan pemahaman konsep peserta didik, kemudian melihat pengaruh dari dua model (flipped classroom dan discovery learning) terhadap kemampuan pemecahan masalah matematis peserta didik, dan yang terakhir untuk melihat pengaruh kedua model pembelajaran (flipped classroom dan discovery learning) terhadap dua kemampuan sekaligus yaitu kemampuan pemahaman konsep dan pemecahan masalah matematis peserta didik.

\section{METODE PENELITIAN}

Quasy Experimental Design merupakan jenis eksperimen yang digunakan dalam penelitian ini, dan desain yang digunakan adalah Posttest Only Control Group Design. Peserta didik kelas XI SMA Negeri 1 Sumber Jaya sebagai populasi penelitian. Teknik sampling yang digunakan adalah cluster random sampling. Sampel terdiri dari 3 kelas yaitu XI IPA 1 diterapkan model flipped classroom, XI IPA 2 diterapkan model discovery learning dan XI IPA 3 diterapkan model direct instruction.

Pengumpulan data yang digunakan adalah observasi dan tes. Kegiatan observasi dilakukan untuk melihat aktivitas kegiatan pembelajaran model flipped classroom, model discovery learning dan model direct instruction. Tes kemampuan pemahaman konsep dan pemecahan masalah disesuaikan dengan indikator. Indikator pemahaman konsep adalah menyatakan ulang sebuah konsep, mengklasifikasikan objek menurut sifat tertentu sesuai dengan konsepnya, memberi contoh dan non contoh, menyajikan konsep dalam bentuk representasi matematis, mengembangkan syarat perlu atau cukup suatu konsep, menggunakan, memanfaatkan, dan memilih prosedur atau operasi tertentu, mengaplikasikan konsep pemecahan masalah (Argikas dan Khuzaini, 2016). Indikator pemecahan masalah adalah memahami masalah, membuat perencanaan, menyelesaikan masalah, memeriksa kembali untuk membuat kesimpulan (Astuti, 2016). Soal yang diberikan berbentuk esay berjumlah 7 butir soal.

Instrumen tes dilakukan uji validitas dan reliabilitas. Uji validitas dilakukan dengan teknik korelasi product moment (Susanto, dkk., 2015). Uji reliabilitas dilakukan dengan rumus Koefisien Cronbach Alpha (Syazali dan Novalia, 2014). Kedua uji tersebut menghasilkan soal valid dan reliabel. 
Teknik analisis data menggunakan uji prasyarat yaitu uji normalitas dan homogenitas. Uji normalitas Lilliefors digunakan untuk mengetahui sampel berasal dari populasi yang normal sedangkan uji homogenitas Bartlett, jika varians yang diperoleh dari populasi yang homogen. Setelah uji prasyarat terpenuhi maka dilanjutkan dengan uji hipotesis menggunakan Uji Manova (Multifariate analisis of varian) dengan bantuan program SPSS 22.0. Uji tersebut dilakukan guna mengetahui pengaruh model flipped classroom, discovery learning dan direct instruction terhadap kemampuan pemahaman konsep dan pemecahan masalah matematis peserta didik

\section{HASIL DAN PEMBAHASAN}

Setelah dilakukan proses pembelajaran kemudian dilakukan post-test yang menghasilkan $X_{\max }$ (nilai tertinggi) dan $X_{\min }$ (nilai terendah) pada masing-masing kelas yaitu dua kelas eksperimen dan kelas kontrol. Selanjutnya dicari ukuran tendensi sentralnya yaitu $\bar{X}$ (rataan), $M_{e}$ (median), $M_{o}$ (modus), serta ukuran varians kelompok yaitu $R$ (jangkauan) dan $s$ (simpang baku), yang kemudian data tersebut disajikan dalam tabel berikut.

Tabel 1. Deskripsi Data Amatan Post-Test Kemampuan Pemahaman Konsep

\begin{tabular}{|c|c|c|c|c|c|c|c|}
\hline \multirow[t]{2}{*}{ Kelas } & \multirow[t]{2}{*}{$X_{\min }$} & \multirow[t]{2}{*}{$X_{\max }$} & \multicolumn{3}{|c|}{$\begin{array}{l}\text { Ukuran Tendensi } \\
\text { Sentral }\end{array}$} & \multicolumn{2}{|c|}{$\begin{array}{c}\text { Ukuran } \\
\text { Variansi } \\
\text { Kelompok }\end{array}$} \\
\hline & & & $\bar{X}$ & $M_{o}$ & $M_{e}$ & $\mathbf{R}$ & $\mathbf{S}$ \\
\hline Model Flipped Classroom & 56 & 100 & 79,7 & 81 & 81 & 44 & 13,25 \\
\hline Model Discovery Learning & 50 & 100 & 70,2 & 75 & 72 & 50 & 15,18 \\
\hline Model Direct Instruction & 44 & 88 & 60,2 & 44 & 56 & 44 & 13,58 \\
\hline
\end{tabular}

Berdasarkan Tabel 1, hasil post-test kemampuan pemahaman konsep pada kelas yang menerapkan model flipped classroom lebih besar dibandingkan dengan kelas yang menerapakan model discovery learning dan model direct instruction.

Tabel 2. Deskripsi Data Amatan Post-Test Kemampuan Pemecahan Masalah

\begin{tabular}{|c|c|c|c|c|c|c|c|}
\hline \multirow[t]{2}{*}{ Kelas } & \multirow[t]{2}{*}{$X_{\min }$} & \multirow[t]{2}{*}{$X_{\max }$} & \multicolumn{3}{|c|}{$\begin{array}{l}\text { Ukuran Tendensi } \\
\text { Sentral }\end{array}$} & \multicolumn{2}{|c|}{$\begin{array}{c}\text { Ukuran } \\
\text { Variansi } \\
\text { Kelompok }\end{array}$} \\
\hline & & & $\bar{X}$ & $M_{o}$ & $M_{e}$ & $\mathbf{R}$ & $\mathbf{S}$ \\
\hline Model Flipped Classroom & 57 & 100 & 78,2 & 87 & 80 & 43 & 12,94 \\
\hline Model Discovery Learning & 47 & 80 & 66,7 & 67 & 68,5 & 33 & 9,99 \\
\hline Model Direct Instruction & 43 & 80 & 60,1 & 60 & 60 & 37 & 12,43 \\
\hline
\end{tabular}

Berdasarkan Tabel 2, hasil post-test kemampuan pemecahan masalah pada kelas yang menerapkan model flipped classroom lebih besar dibandingkan dengan kelas yang 
menerapakan model discovery learning dan model direct instruction. Akan tetapi nilai $\mathrm{R}$ (jangkauan) pada model flipped classroom masih cukup besar dibandingkan dengan model discovery learning dan direct instruction yaitu 43. Angka tersebut menunjukan masih tingginya selisih antara nilai tertinggi dengan nilai terendah. Dapat disimpulkan bahwa dengan menggunakan model flipped classroom masih terdapat peserta didik yang memiliki kemampuan pemecahan masalah yang masih rendah.

Berdasarkan uraian di atas dapat disimpukan bahwa menggunakan model flipped classroom lebih baik dibandingkan dengan model discovery learning dan direct instruction. Sehingga pembelajaran dengan model flipped classroom lebih efektif untuk meningkatkan kemampuan pemahaman konsep dan pemecahan masalah peserta didik.

Hasil perhitungan uji normalitas kemampuan pemahaman konsep dan pemecahan masalah matematis yang disajikan dalam Tabel 3.

Tabel 3. Hasil Uji Normalitas Kemampuan Pemahaman Konsep dan Pemecahan Masalah Matematis

\begin{tabular}{|c|c|c|c|c|c|c|}
\hline No & Kelas & Kemampuan & $N$ & $L_{\text {hitung }}$ & $L_{t a b e l}$ & $\begin{array}{c}\text { Keputusan } \\
\text { Uji }\end{array}$ \\
\hline \multirow{2}{*}{ 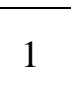 } & Model Flipped & Pemahaman Konsep & \multirow{2}{*}{31} & 0,0903 & 0,1559 & $H_{0}$ diterima \\
\hline & classroom & Pemecahan Masalah & & 0,1143 & 0,1559 & $H_{0} \mathrm{c}$ \\
\hline \multirow{2}{*}{2} & Model Discovery & Pemahaman Konsep & \multirow{2}{*}{31} & 0,1482 & 0,1559 & $H_{0}$ diterima \\
\hline & Learning & Pemecahan Masalah & & 0,1255 & 0,1559 & $H_{0}$ diterima \\
\hline \multirow{2}{*}{3} & Model Direct & Pemahaman Konsep & \multirow{2}{*}{31} & 0,1382 & 0,1559 & $H_{0}$ diterima \\
\hline & Instruction & Pemecahan Masalah & & 0,1460 & 0,1559 & $H_{0}$ diterima \\
\hline
\end{tabular}

Berdasarkan Tabel 3, terlihat dari ketiga kelas tersebut menunjukan bahwa $L_{\text {hitung }} \leq L_{\text {tabel }}$ dengan taraf signifikansi $5 \%$ atau 0,05 yang berarti $H_{0}$ diterima. Sehingga dapat disimpulan bahwa sampel berasal dari populasi yang berdistribusi normal.

Hasil perhitungan uji homogenitas kemampuan pemahaman konsep dan pemecahan masalah matematis yang disajikan dalam Tabel 4.

Tabel 4. Hasil Uji Homogenitas Kemampuan Pemahaman Konsep dan Pemecahan Masalah Matematis

\begin{tabular}{cccc}
\hline Kemampuan & $\boldsymbol{X}^{\mathbf{2}}{ }_{\text {hitung }}$ & $\boldsymbol{X}^{\mathbf{2}}$ tabel & Keputusan \\
\hline Pemahaman Konsep & 0,643 & 5,591 & $H_{0}$ diterima \\
Pemecahan Masalah & 2,201 & 5,591 & $H_{0}$ diterima \\
\hline
\end{tabular}

Berdasarkan Tabel 4, uji homogenitas kemampuan pemahaman konsep dan pemecahan masalah dengan taraf signifikansi 5\% atau 0,05 dan $x_{\text {tabel }}^{2}=x_{\alpha, k-1}^{2}=x_{0,05,2}^{2}=5,591$ menunjukan bahwa $x^{2}{ }_{\text {hitung }} \leq x_{\text {tabel }}^{2}$ maka sampel berasal dari populasi yang homogen. 
Setelah diperoleh data berdistribusi normal dan berasal dari populasi yang homogen maka selanjutnya dilakukan uji hipotesis dengan menggunakan uji MANOVA. Uji Manova dihitung dengan bantuan program SPSS 22.0. Uji yang pertama dilakukan adalah Test of Between-Subjects Effects atau uji pengaruh antar subjek/variabel. Hasil dari Test of Between-Subjects Effects disajikan dalam Tabel 5.

Tabel 5. (Test of Between-Subjects Effects)

\begin{tabular}{ccccccc}
\hline Source & Dependent variable & $\begin{array}{c}\text { Type III Sum } \\
\text { of Square }\end{array}$ & Df & $\begin{array}{c}\text { Mean } \\
\text { Square }\end{array}$ & F & Sig. \\
\hline \multirow{2}{*}{ Kelas } & Pemahaman Konsep & 5904,839 & 2 & 2952,419 & 14,990 & 0,000 \\
& Pemecahan Masalah & 5185,570 & 2 & 2592,785 & 18,431 & 0,000 \\
\hline
\end{tabular}

Berdasarkan Tabel 5, terlihat bahwa kemampuan pemahaman konsep dan pemecahan masalah didapat signifikansi 0,000 dengan derajat angka signifikansi yang dipakai 0,05 atau 5\%. Sehingga $H_{0 A}$ ditolak dan $H_{1 A}$ diterima, dapat disimpulkan bahwa terdapat pengaruh model pemebelajaran Flipped Classroom, Discovery Learning, dan Direct Instruction terhadap kemampuan pemahaman konsep dan terdapat pengaruh model pemebelajaran Flipped Classroom, Discovery Learning, dan Direct Instruction terhadap kemampuan pemecahan masalah matematis peserta didik.

Selanjutnya dilakukan uji Multivariate guna mengetahui pengaruh dari model pembelajaran terhadap kemampuan pemahaman konsep dan pemecahan masalah matematis secara bersamaan (silmultan). Hasil dari uji Multivariate disajikan dalam Tabel 6.

Tabel 6. Uji Multivariate

\begin{tabular}{lcccccc}
\hline \multicolumn{1}{c}{ Effect } & & Value & F & $\begin{array}{c}\text { Hypothesis } \\
\text { df }\end{array}$ & Error df & Sig. \\
\hline $\begin{array}{l}\text { Model } \\
\text { pembelajaran } \\
\text { terhadap } \\
\text { kemampuan } \\
\text { pemahaman }\end{array}$ & Pillai's trace & 0,351 & 9,594 & 4,000 & 180.000 & 0,000 \\
$\begin{array}{l}\text { konsep dan } \\
\text { pemecahan }\end{array}$ & $\begin{array}{c}\text { Lilks' } \\
\text { mamalah } \\
\text { matematis }\end{array}$ & 0,652 & $10,624^{\mathrm{b}}$ & 4,000 & 178,000 & 0,000 \\
& $\begin{array}{c}\text { Hotelling's } \\
\text { trace } \\
\text { Roy's }\end{array}$ & 0,530 & 11,652 & 4,000 & 176,000 & 0,000 \\
\hline
\end{tabular}

Berdasarkan Tabel 6, terlihat bahwa uji perbandingan diambil dari rata-rata komponen kemampuan pemahaman konsep dan pemecahan masalah matematis menggunakan perlakuan (eksperimen 1, eksperimen 2 dan kontrol) terdapat uji statistik pillai's trace, wilks' lambda, hotelling's trace, dan roy's largest root. Didapatkan p-value $<0,05$ yang sesuai dengan kriteria bahwa $H_{0 A B}$ ditolak dan $H_{1 A B}$ diterima sehingga dapat 
ditarik kesimpulan bahwa terdapat pengaruh model pembelajaran Flipped Classroom, Discovery Learning dan Direct Instruction terhadap kemampuan pemahaman konsep dan pemecahan masalah matematis peserta didik.

Selanjutnya dilakukan uji Tukey sebagai uji lanjut guna mengetahui perbedaan dari ketiga model. Hasil dari uji Tukey disajkan pada Tabel 7.

Tabel 7. Uji Tukey

\begin{tabular}{|c|c|c|c|c|c|c|c|}
\hline \multirow[b]{2}{*}{$\begin{array}{l}\text { Dependent } \\
\text { Variable }\end{array}$} & \multirow[b]{2}{*}{ (I) kelas } & \multirow[b]{2}{*}{ (J) kelas } & \multirow{2}{*}{$\begin{array}{l}\text { Mean } \\
\text { Difference } \\
\text { (I-J) }\end{array}$} & \multirow[b]{2}{*}{$\begin{array}{l}\text { Std. } \\
\text { Error }\end{array}$} & \multirow[b]{2}{*}{ Sig. } & \multicolumn{2}{|c|}{$\begin{array}{c}\text { 95\% Confidence } \\
\text { Interval }\end{array}$} \\
\hline & & & & & & $\begin{array}{l}\text { Lower } \\
\text { Bound }\end{array}$ & $\begin{array}{l}\text { Upper } \\
\text { Bound }\end{array}$ \\
\hline \multirow[t]{6}{*}{$\begin{array}{l}\text { Pemahaman } \\
\text { Konsep }\end{array}$} & $\begin{array}{l}\text { Flipped } \\
\text { Classroom }\end{array}$ & $\begin{array}{l}\text { Discovery } \\
\text { Learning }\end{array}$ & $9.52^{*}$ & 3.565 & .024 & 1.02 & 18.01 \\
\hline & & $\begin{array}{l}\text { Direct } \\
\text { Instruction }\end{array}$ & $19.52^{*}$ & 3.565 & .000 & 11.02 & 28.01 \\
\hline & $\begin{array}{l}\text { Discovery } \\
\text { Learning }\end{array}$ & $\begin{array}{l}\text { Flipped } \\
\text { Classroom }\end{array}$ & $-9.52^{*}$ & 3.565 & .024 & -18.01 & -1.02 \\
\hline & & $\begin{array}{l}\text { Direct } \\
\text { Instruction }\end{array}$ & $10.00^{*}$ & 3.565 & .017 & 1.50 & 18.50 \\
\hline & $\begin{array}{l}\text { Direct } \\
\text { Instruction }\end{array}$ & $\begin{array}{l}\text { Flipped } \\
\text { Classroom }\end{array}$ & $-19.52^{*}$ & 3.565 & .000 & -28.01 & -11.02 \\
\hline & & $\begin{array}{l}\text { Discovery } \\
\text { Learning }\end{array}$ & $-10.00^{*}$ & 3.565 & .017 & -18.50 & -1.50 \\
\hline \multirow[t]{6}{*}{$\begin{array}{l}\text { Pemecahan } \\
\text { Masalah }\end{array}$} & $\begin{array}{l}\text { Flipped } \\
\text { Classroom }\end{array}$ & $\begin{array}{l}\text { Discovery } \\
\text { Learning }\end{array}$ & $11.52^{*}$ & 3.013 & .001 & 4.34 & 18.70 \\
\hline & & $\begin{array}{l}\text { Direct } \\
\text { Instruction }\end{array}$ & $18.06^{*}$ & 3.013 & .000 & 10.89 & 25.24 \\
\hline & $\begin{array}{l}\text { Discovery } \\
\text { Learning }\end{array}$ & $\begin{array}{l}\text { Flipped } \\
\text { Classroom }\end{array}$ & $-11.52^{*}$ & 3.013 & .001 & -18.70 & -4.34 \\
\hline & & $\begin{array}{l}\text { Direct } \\
\text { Instruction }\end{array}$ & 6.55 & 3.013 & .081 & -.63 & 13.73 \\
\hline & $\begin{array}{l}\text { Direct } \\
\text { Instruction }\end{array}$ & $\begin{array}{l}\text { Flipped } \\
\text { Classroom }\end{array}$ & $-18.06^{*}$ & 3.013 & .000 & -25.24 & -10.89 \\
\hline & & $\begin{array}{l}\text { Discovery } \\
\text { Learning }\end{array}$ & -6.55 & 3.013 & .081 & -13.73 & .63 \\
\hline
\end{tabular}

Berdasarkan Tabel 7, terlihat bahwa pada kemampuan pemahaman konsep untuk kelas yang diterapkan model flipped classroom memiliki perbedaan nyata dengan kelas model discovery learning dan kelas model direct instruction, serta kelas yang diterapkan model discovery learning memiliki perbedaan nyata dengan kelas model direct instruction. Sedangkan pada kemampuan pemecahan masalah hanya kelas yang diterapkan model flipped classroom yang memiliki perbedaan nyata dengan kelas model discovery learning dan kelas model direct instruction. Model pembelajaran yang terbaik untuk meningkatkan kemampuan pemahaman konsep dan pemecahan masalah matematis diantara ketiga model adalah model flipped classroom. 
Karakteristik pembelajaran dengan model flipped classroom adalah kegiatan pembelajaran terbalik atau kegiatan pembelajaran yang di lakukan di sekolah, peserta didik melakukannya di rumah dan tugas yang biasanya dikerjakan di rumah, peserta didik kerjakan di sekolah (Oakes, Davies, Joubert, \& Lyakhova, 2018). Langkah awal model flipped classroom dengan pemberian video sebelum proses pembelajaran di kelas berlangsung, langkah model flipped classroom ini memiliki pengaruh berbeda terhadap kemampuan pemahaman konsep dan pemecahan masalah. Pemberian video sangat membantu peserta didik, hal ini karena kemampuan peserta didik dalam satu kelas berbeda-beda. Peserta didik dapat memutar video berulang-ulang apabila belum memahami materi, selain itu video juga dapat diputar kapan saja sesuai dengan waktu belajar peserta didik. Kesadaran peserta didik tentang pentingnya menonton video sebelum proses pembelajaran berlangsung menjadi bekal pemahaman mengenai konsep-konsep materi dalam menyelesaikan permasalahan pada soal. Peserta didik dapat memecahkan permasalahan dalam soal sesuai dengan langkah-langkah yang terdapat pada contoh soal yang dijelaskan dalam video .

Model flipped classroom membagi peserta didik menjadi kelompok untuk mendiskusikan materi, proses diskusi dengan teman kelompok sangat membangun perkembangan kognitif peserta didik. Peserta didik diberi permasalahan yang kemudian dipersentasikan, pada proses presentasi terjadi proses tanya jawab antar peserta didik dalam satu kelas. Kemudian peserta didik menyimpulkan dari kegiatan pembelajaran dan diberikan kesempatan bertanya kepada pendidik. Penerapan model Flipped Classroom berpengaruh terhadap hasil kemampuan pemahaman konsep dan pemecahan masalah matematis peserta didik.

Penelitian yang sesuai dengan hasil tersebut adalah penelitian (Juniantari, dkk., 2018) menyatakan bahwa penerapan model flipped classroom memberikan pengaruh positif terhadap pemahaman konsep peserta didik. Penelitian lain dari (Ismiati, dkk., 2020) menyatakan bahwa pembelajaran dengan model flipped classroom berbasis proyek kemampuan pemecahan masalah peserta didik tergolong tinggi. Hasil penelitian lain yang mendukung hasil tersebut adalah penelitian (Fikri, 2019) menyatakan bahwa model pembelaaran flipped classroom mampu membantu peserta didik untuk meningkatakan kemampuan pemahaman konsep. Penelitian lain dari (Alanda, dkk., 2019) kemampuan pemecahan masalah matematis peserta didik lebih baik dengan diterapkan model flipped classroom. 
Tahap awal model discovery learning adalah stimulation, pada tahap ini peserta didik diberi apersepsi, kemudian peserta didik mengidentifikasi masalah dan membuat hipotesis sendiri pada tahap problem statement, setelah itu masuk ke tahap data collecting yaitu peserta didik mengumpulkan informasi yang relavan sebanyak mungkin, dari data yang sudah didapatkan data tahap sebelumnya kemudian peserta didik masuk ke tahap berikutnya yaitu data processing atau mengolah data, selanjutnya dilakukan pembuktian atas hipotesis yang sudah dibuat pada tahap problem statement yang disebut tahap verification dan yang terakhir adalah tahap generalization, pada tahap ini peserta didik menyimpulkan dari hasil verifikasi . Karakteristik pembelajaran dengan model discovery learning menuntut peserta didik untuk melakukan penemuan suatu konsep, langkah model discovery learning yang memiliki pengaruh berbeda terhadap kemampuan pemahaman konsep dan pemecahan masalah adalah tahap data collecting, pada tahap collecting peserta didik dituntut berperan aktif untuk mengumpulkan informasi serta menemukan suatu konsep. Peserta didik mampu mengembangkan dan menemukan sendiri konsep dari beberapa referensi sehingga peserta didik lebih paham dan mampu mengingat lebih lama serta pemahaman konsepnya lebih baik. kegiatan di dalam kelas berpusat pada peserta didik sehingga peserta didik lebih mampu mendalami konsep yang telah dipelajari untuk menemukan konsep baru yang kemudian diterapkan dalam pemecahan masalah. Penerapan model discovery learning berpengaruh terhadap hasil kemampuan pemahaman konsep dan pemecahan masalah matematis peserta didik.

Hasil penelitian lain yang mendukung hasil tersebuat adalah penelitian Sihotang (2018) menyatakan bahwa kemampuan pemahaman konsep peserta didik lebih tinggi dengan penerapan model discovery learning dibandingkan dengan model konvensional. Penelitian lain dari Jana dan Fahmawati (2020), menyatakan bahwa kemampuan pemecahan masalah matematis peserta didik kelas VIII C SMP PGRI Kasihan meningkat dengan diterapkannya model discovery learning. Hasil penelitian lain yang mendukung adalah penelitian Caprio, dkk. (2019), penelitian tersebut menyatakan bahwa penerapan model discovery learning memberikan pengaruh terhadap kemampuan pemahaman konsep. Penelitian lain dari Marantika, dkk. (2015) menyatakan bahwa terdapat pengaruh model discovery learning terhadap kemampuan pemecahan masalah matematis peserta didik.

Berdasarkan penelitian yang sudah dilakukan dan melihat hasil posttest peserta didik, menunjukan bahwa penerapan model flipped classroom lebih baik dibandingkan dengan model discovery learning. Penelitian lain yang mendukung adalah menyatakan 
bahwa prestasi belajar peserta didik lebih baik dengan penerapan model flipped classroom dari pada model discovery learning (Yulietri, dkk., 2015). Hasil penelitian lain yang mendukung menyatakan bahwa pemahaman konsep biologi peserta didik masuk dalam kategori rendah pada pembelajaran dengan model discovery learning (Patrianingsih dan Kaseng, 2017).

\section{KESIMPULAN}

Penelitian ini menunjukan bahwa terdapat pengaruh model (flipped classroom dan discovery learning) terhadap kemampuan pemahaman konsep, terdapat pengaruh model (flipped classroom dan discovery learning) terhadap pemecahan masalah dan terdapat pengaruh model (flipped classroom dan discovery learning) terhadap kemampuan pemahaman konsep dan pemecahan masalah matematis peserta didik. Model flipped classroom lebih baik dibandingkan dengan model discovery learning dan model direct instruction untuk meningkatkan kemampuan pemahaman konsep dan pemecahan masalah matematis peserta didik.

\section{REFERENSI}

Alanda, Y., Mustangin, \& Hasana, S. N. (2019). Kemampuan Pemecahan Masalah dan Berpikir Kritis Matematis melalui Model Flipped Classroom dengan Media Edmodo pada Materi Bangun Ruang Sisi Datar. JP3, 14(6), 24-32.

Argikas, T. B., \& Khuzaini, N. (2016). Penerapan Model Pembelajaran Reciprocal Teaching Untuk Meningkatkan Pemahaman Konsep Matematika Siswa Kelas Vii Smp Negeri 2 Depok. Jurnal Mercumatika, 1(1), 67-79.

Astuti, D. (2016). Kemampuan Pemahaman Matematis melalui Model Pembelajaran Student Teams Achievement Development ( STAD ). Journal of Mathematics Education, 2(1), 79-89.

Caprio, R. R., Noer, S. H., \& Wijaya, A. P. (2019). Pengaruh Model Pembelajaran Discovery terhadap Pemahaman Konsep Matematis Siswa. Jurnal Pendidikan Matemaika, 7(5), 630-644.

Fikri, S. A. (2019). Flipped Classroom terhadap Kemampuan Pemahaman Konsep Matematis Siswa. Prosiding Sendika, 5(1), 325-330.

Hayati, R. (2018). Flipped Classroom dalam Pembelajaran Matematika: Sebuah Kajian Teoritis. Prosiding Seminar Nasional Matematika dan Pendidikan Matematika, “ Integrasi Budaya, Psikologi, dan Teknologi dalam Membangun Pendidikan Karakter Melalui Matematika dan Pembelajarannya."

Hikmawati, N. N., Nurcahyono, N. A., \& Balkist, P. S. (2019). Kemampuan Komunikasi Matematis Siswa dalam Menyelesaikan Soal Geometri Kubus dan Balok. PRISMA, 8(1), 68. https://doi.org/10.35194/jp.v8i1.648

Ismiati, I., Sarwi, S., \& Marwoto, P. (2020). Pola dan Kemampuan Pemecahan Masalah Peserta Didik melalui Pembelajaran Flipped Classroom Berbasis Proyek. ORBITA: Jurnal Kajian, Inovasi Dan Aplikasi Pendidikan Fisika, 6(1), 115-123. https://doi.org/10.31764/orbita.v6i1.1847 
Jana, P., \& Fahmawati, A. A. N. (2020). Model Discovery Learning untuk Meningkatkan Kemampuan Pemecahan Masalah. AKSIOMA: Jurnal Program Studi Pendidikan Matematika, 9(1), 213-220. https://doi.org/10.24127/ajpm.v9i1.2157

Jarwan. (2018). Pengaruh Discovery Learning terhadap Kemampuan Pemecahan Masalah dan Komunikasi Matematis Siswa. PROXIMAL, 1(2), 77-89.

Juniantari, M., Pujawan, I. G. N., \& Widhiasih, I. D. A. G. (2018). Pengaruh Pendekatan Flipped Classroom terhadap Pemahaman Konsep Matematika Siswa SMA. Journal of Education Technology, 2(4), 197-204. https://doi.org/10.23887/jet.v2i4.17855

Jusniani, N. (2018). Analisis Kesalahan Jawaban Siswa pada Kemampuan Pemahaman Matematis melalui Pembelajaran Kontekstual. PRISMA, $7(1), \quad 82$. https://doi.org/10.35194/jp.v7i1.361

Karimah, W. (2018). Penerapan Model Flipped Classroom Berbantuan Video Pembelajaran terhadap Kemampuan Pemecahan Masalah Matematika Siswa. Delta: Jurnal Ilmiah Pendidikan Matematika, 6(2), 25-32. https://doi.org/10.31941/delta.v6i2.913

Khoirotunnisa', A. U. (2017). Eksperimentasi Model Pembelajaran Jigsaw Puzzle Map Terhadap Prestasi Belajar Matematika Materi Himpunan Ditinjau dari Tipe Kepribadian Siswa Kelas VII Semester 1 MTsN 1 Bojonegoro Tahun Ajaran 2015/2016. JIPM (Jurnal Ilmiah Pendidikan Matematika), 5(2), 82-88. https://doi.org/10.25273/jipm.v5i2.1171

Kusmawati, L., \& Ginanjar S, G. (2016). Peningkatan Kemampuan Pemahaman Konsep Perkalian melalui Pendekatan Pembelajaran Konstruktivisme Pembelajaran Matematika di Kelas 3 SDN Cibaduyut 4. Didaktik: Jurnal Ilmiah PGSD STKIP Subang, 1(2), 262-271. https://doi.org/10.36989/didaktik.v1i2.32

Marantika, A., Handayani, T., \& Putri, D. A. (2015). Pengaruh Metode Discovery Learning terhadap Kemampuan Pemecahan Masalah Matematika Siswa pada Pembelajaran Matematika di SMP Pelita Palembang. Jurnal Pendidikan Matematika JPM RAFA, 1(2), 161-183.

Monariska, E. (2017). Penerapan Metode Mind Mapping untuk Meningkatkan Kemampuan Pemahaman Konsep Matematis Mahasiswa pada Mata Kuliah Kalkulus I. PRISMA, 6(1), 17-31. https://doi.org/10.35194/jp.v6i1.25

Nurhasanah, D. E., Kania, N., \& Sunendar, A. (2018). Penggunaan Model Pembelajaran Discovery Learning untuk Meningkatkan Kemampuan Pemecahan Masalah pada Siswa SMP. Jurnal Didactical Mathematics, 1(1), 21-32. https://doi.org/10.31949/dmj.v1i1.1113

Oakes, D., Davies, A., Joubert, M., \& Lyakhova, S. (2018). Exploring teachers' and students' responses to the use of a Flipped Classroom teaching approach in mathematics. BSRLM, 38(November), 1-6.

Patrianingsih, E. A., \& Kaseng, E. S. (2017). Model Pembelajaran Discovery Learning, Pemahaman Konsep Biologi, dan Sikap Ilmiah Peserta Didik SMA Negri 3 Takalar. UNM Journal of Biological Education, 1(1), 31-46.

Saputra, M. E. A., \& Mujib, M. (2018). Efektivitas Model Flipped Classroom Menggunakan Video Pembelajaran Matematika terhadap Pemahaman Konsep. Desimal: Jurnal Matematika, 1(2), 173-179. https://doi.org/10.24042/djm.v1i2.2389

Septian, A., Darhim, \& Prabawanto, S. (2020). Geogebra in integral areas to improve mathematical representation ability. Journal of Physics: Conference Series, 1613(1), 012035. https://doi.org/10.1088/1742-6596/1613/1/012035

Septian, A., \& Ramadhanty, C. L. (2020). Peningkatan Pemahaman Konsep Matematika Siswa SMP melalui Model Pembelajaran Kooperatif Tipe Jigsaw. WACANA AKADEMIKA: Majalah Ilmiah Kependidikan, 4(1), 56-63. 
https://doi.org/10.30738/wa.v4i1.7782

Sihotang, V. (2018). Pengaruh Model Pembelajaran Discovery Learning Terhadap Kemampuan Pemahaman Konsep Matematis Siswa Kelas IX SMP Negeri 5 Sumbul. Cartesius: Jurnal Pendidikan Matematika, 1(1), 62-74.

Susanto, H., Rinaldi, A., \& Novalia. (2015). Analisis Validitas Reabilitas Tingkat Kesukaran dan Daya Beda pada Butir Soal Ujian Akhir Semester Ganjil Mata Pelajaran Matematika. Al-Jabar:Jurnal Pendidikan Matematika, 6(2), 203-217.

Syazali, M., \& Novalia. (2014). Olah Data Penelitian Pendidikan. Bandar Lampung: Aura. Trianingsih, A., Husna, N., \& Prihatiningtyas, N. C. (2019). Pengaruh Model Discovery Learning terhadap Pemahaman Konsep Matematis Siswa pada Materi Persamaan Lingkaran di Kelas XI IPA. Variabel, 2(1), 1-8. https://doi.org/10.26737/var.v2i1.1026

Widiyawati, W., Septian, A., \& Inayah, S. (2020). Analisis Kemampuan Koneksi Matematis Siswa SMK pada Materi Trigonometri. Jurnal Analisa, 6(1), 28-39. https://doi.org/10.15575/ja.v6i1.8566

Widyastuti, R. (2015). Proses Berfikir Siswa dalam Menyelesaikan Masalah Matematika berdasarkan Teori Polya ditinjau dari Adversity Quotient Tipe Climber. Al-Jabar: Jurnal Pendidikan Matematika, 6(2), 183-193.

Yulietri, F., Mulyoto, \& Agung S, L. (2015). Model Flipped Classroom dan Discovery Learning Pengaruhnya terhadap Prestasi Belajar Matematika Ditinjau dari Kemandirian Belajar. TEKNODIKA, 13(2), 5-17. 